\title{
2-S-Lipoylcaffeic Acid, a Natural Product-Based Entry to Tyrosinase Inhibition via Catechol Manipulation
}

\author{
Raffaella Micillo ${ }^{1}$, Valeria Pistorio ${ }^{2}$ (D), Elio Pizzo ${ }^{2}$, Lucia Panzella ${ }^{1, *}$, \\ Alessandra Napolitano ${ }^{1}$ (i) and Marco d'Ischia ${ }^{1}$ \\ 1 Department of Chemical Sciences, University of Naples "Federico II", Via Cintia 4, I-80126 Naples, Italy; \\ raffaella.micillo@unina.it (R.M.); alesnapo@unina.it (A.N.); dischia@unina.it (M.d.I.) \\ 2 Department of Biology, University of Naples "Federico II", Via Cintia 4, I-80126 Naples, Italy; \\ valeria.pistorio@gmail.com (V.P.); elipizzo@unina.it (E.P.) \\ * Correspondence: panzella@unina.it; Tel.: +39-081-674131
}

Academic Editor: Ille C. Gebeshuber

Received: 24 July 2017; Accepted: 9 August 2017; Published: 10 August 2017

\begin{abstract}
Conjugation of naturally occurring catecholic compounds with thiols is a versatile and facile entry to a broad range of bioinspired multifunctional compounds for diverse applications in biomedicine and materials science. We report herein the inhibition properties of the caffeic acid- dihydrolipoic acid S-conjugate, 2-S-lipoylcaffeic acid (LC), on mushroom tyrosinase. Half maximum inhibitory concentration $\left(\mathrm{IC}_{50}\right)$ values of $3.22 \pm 0.02$ and $2.0 \pm 0.1 \mu \mathrm{M}$ were determined for the catecholase and cresolase activity of the enzyme, respectively, indicating a greater efficiency of LC compared to the parent caffeic acid and the standard inhibitor kojic acid. Analysis of the Lineweaver-Burk plot suggested a mixed-type inhibition mechanism. LC proved to be non-toxic on human keratinocytes (HaCaT) at concentrations up to $30 \mu \mathrm{M}$. These results would point to LC as a novel prototype of melanogenesis regulators for the treatment of pigmentary disorders.
\end{abstract}

Keywords: depigmenting agents; L-DOPA; dopachrome; tyrosinase; melanin; caffeic acid; dihydrolipoic acid; lipoic acid; keratinocytes

\section{Introduction}

Several pigmentary disorders, such as melasma or lentigo, are associated with the overproduction or accumulation of melanin as the result of inflammatory responses or abnormal function of melanocytes inducing a local excess of pigmentation known as "hypermelanosis" [1-3]. The medical and aesthetical unfavorable impact of such disorders has prompted a constant search for new non-toxic depigmenting agents [4-6].

Since skin complexion is under control of several factors, including activity, expression, and stability of tyrosinase and related enzymes, melanocytes homeostasis, and melanosome transfer to the keratinocytes, commercially available depigmenting agents and melanogenesis regulators usually act through different mechanisms $[7,8]$.

One of the most common approaches for control of pigmentation involves the inhibition of tyrosinase (EC 1.14.18.1) [9,10], a copper-containing enzyme exhibiting cresolasic or monophenolasic activity (hydroxylation of monophenols to $o$-diphenols) and catecholasic or diphenolasic activity (dehydrogenation of catechols to $o$-quinones) by a mechanism involving electron exchange with the copper atoms. In particular, tyrosinase catalyzes the key steps of melanogenesis, namely the hydroxylation and oxidation of L-tyrosine to dopaquinone [11,12].

When considering a new tyrosinase inhibitor several factors should be taken into account, such as product efficacy, cytotoxicity, solubility, cutaneous absorption, and stability. Increasing attention has been paid to the adverse effects of depigmenting agents in vitro and in vivo, especially further 
to the case of rhododendrol, a phenolic skin whitening agent that has been recently withdrawn from the market because of its cytotoxic effects on melanocytes and the consequent induction of leukoderma [13-16]. This has been ascribed to the tyrosinase-catalyzed oxidation of rhododendrol producing toxic metabolites [14-17].

Several catecholic compounds have raised interest due to their tyrosinase inhibition properties [18-21]. Among the catecholic compounds of natural origin, a prominent position is occupied by caffeic acid (3,4-dihydroxycinnamic acid) due to its health-beneficial properties [22-24]. A number of caffeic acid derivatives, mostly amides, have been described as tyrosinase inhibitors, while caffeic acid is not, and this ability has been attributed to both the structural similarity of the caffeic acid moiety to the substrate 3,4-dihydroxy-L-phenylalanine (L-DOPA) [20] and to the hydrophobicity and copper-chelating properties imparted by the particular nitrogen substituents [25-28].

Recently, with a view to synthesizing multifunctional antioxidants inspired to bioactive thiol-conjugates of naturally occurring phenolic compounds [29-35], we have focused our attention to dihydrolipoic acid (DHLA), the reduced form of lipoic acid (LA). The LA/DHLA system is known to be a powerful antioxidant being able to reduce reactive oxygen species, scavenge hydroxyl radicals, hypochlorous acid, and peroxynitrite, and chelate $\mathrm{Fe}^{2+}$ ions; moreover, LA and its reduced form can exert their functions both in membrane and in cytoplasm, because of their solubility in fats and water $[36,37]$. DHLA has also been reported to react with dopaquinone to give lipoyl-DOPA conjugates, and such a kind of reaction is able to affect melanin production resulting in depigmentation [38,39].

On this basis, we report herein the tyrosinase inhibition properties of a conjugate of DHLA with caffeic acid, namely 2-S-lipoylcaffeic acid (LC) (Figure 1).<smiles>O=C(O)/C=C/c1ccc(O)c(O)c1SCCC(S)CCCCC(=O)O</smiles>

Figure 1. Structure of 2-S-lipoylcaffeic acid (LC).

\section{Materials and Methods}

\subsection{Materials}

2-Iodobenzoic acid, oxone ${ }^{\circledR},( \pm)$-LA, sodium borohydride, sodium dithionite, L-DOPA, mushroom tyrosinase (EC 1.14.18.1), p-coumaric acid, caffeic acid, kojic acid, and 3-(4,5-dimethyl-2thiazolyl)-2,5-diphenyl-2H-tetrazolium bromide (MTT) were purchased from Sigma-Aldrich (Milan, Italy). Dulbecco's modified Eagle medium (DMEM), L-glutamine, penicillin/streptomycin, and fetal bovine serum (FBS) were purchased from Euroclone (Milan, Italy). All solvents were high-performance liquid chromatography (HPLC) grade. Double-distilled deionized water was used throughout the study.

2-Iodoxybenzoic acid (IBX) [40] and DHLA [41] were synthetized as reported.

\subsection{Methods}

Ultraviolet-visible (UV-Vis) spectra were recorded on a Jasco V-730 spectrophotometer (Lecco, Italy). Nuclear magnetic resonance (NMR) spectra were recorded at $400 \mathrm{MHz}$ on a Bruker instrument (Milan, Italy).

HPLC analyses were performed on an Agilent 1100 binary pump instrument (Agilent Technologies, Milan, Italy) equipped with a UV-Vis detector, using an octadecylsilane-coated column, $250 \mathrm{~mm} \times 4.6 \mathrm{~mm}$, 
$5 \mu \mathrm{m}$ particle size (Phenomenex SphereClone ODS, Bologna, Italy) at $0.7 \mathrm{~mL} / \mathrm{min}$, and the following gradient: $0.1 \%$ formic acid (eluent a)/methanol (eluent b): $40 \%$ b, 0-10 min; from 40 to $80 \%$ b, 10-47.5 min. The detection wavelength was set at $280 \mathrm{~nm}$.

Liquid chromatography-mass spectrometry (LC-MS) analysis was performed on an HPLC $1100 \mathrm{VL}$ series instrument (Agilent Technologies) with an electrospray ionization source in positive ion mode (ESI+). An Agilent Eclipse XDB-C18, $150 \mathrm{~mm} \times 4.60 \mathrm{~mm}, 5 \mu \mathrm{m}$ (Agilent Technologies) was used, with the same eluent used for the HPLC analysis at a flow rate of $0.4 \mathrm{~mL} / \mathrm{min}$. Mass spectra were registered under the following conditions: nebulizer pressure $50 \mathrm{psi}$; drying gas (nitrogen) flow $10 \mathrm{~L} / \mathrm{min}$, at $350^{\circ} \mathrm{C}$; and capillary voltage $4000 \mathrm{~V}$.

\subsection{Synthesis of 2-S-Lipoylcaffeic Acid}

A solution of $p$-coumaric acid $(215 \mathrm{mg}, 1.3 \mathrm{mmol})$ in methanol $(18 \mathrm{~mL})$ was treated with IBX (561 mg, $2 \mathrm{mmol}$ ) under vigorous stirring at room temperature. After $7 \mathrm{~min}$ a solution of DHLA (1.12 g, $5.3 \mathrm{mmol})$ in methanol $(18 \mathrm{~mL})$ was added dropwise, and after additional $15 \mathrm{~min}$ the reaction mixture was diluted with water and acidified to $\mathrm{pH} 1$ with $6 \mathrm{M} \mathrm{HCl}$. The mixture was then washed with hexane/toluene 8:2 $v / v(10 \times 200 \mathrm{~mL})$ and extracted with chloroform $(7 \times 200 \mathrm{~mL})$. The combined chloroform layers were dried over sodium sulfate and taken to dryness to afford pure LC (101 mg, $20 \%$ yield) as a yellow oil.

ESI+/MS: $m / z 387\left([\mathrm{M}+\mathrm{H}]^{+}\right), 409\left([\mathrm{M}+\mathrm{Na}]^{+}\right) ; \mathrm{UV}: \lambda_{\max }\left(\mathrm{CH}_{3} \mathrm{OH}\right) 252,320 \mathrm{~nm} ;{ }^{1} \mathrm{H}-\mathrm{NMR}\left(\mathrm{CD}_{3} \mathrm{OD}\right)$ : $\delta(\mathrm{ppm}) 1.38(\mathrm{~m}, 1 \mathrm{H}), 1.54(\mathrm{~m}, 1 \mathrm{H}), 1.54(\mathrm{~m}, 2 \mathrm{H}), 1.42(\mathrm{~m}, 1 \mathrm{H}), 1.62(\mathrm{~m}, 1 \mathrm{H}), 1.78(\mathrm{~m}, 1 \mathrm{H}), 1.81(\mathrm{~m}, 1 \mathrm{H})$, $2.26(\mathrm{~m}, 2 \mathrm{H}), 2.88(\mathrm{~m}, 1 \mathrm{H}), 2.90(\mathrm{~m}, 1 \mathrm{H}), 2.96(\mathrm{~m}, 1 \mathrm{H}), 6.29(\mathrm{~d}, J=16 \mathrm{~Hz}, 1 \mathrm{H}), 6.86(\mathrm{~d}, J=8.4 \mathrm{~Hz}, 1 \mathrm{H})$, $7.22(\mathrm{~d}, J=8.4 \mathrm{~Hz}, 1 \mathrm{H}), 8.40(\mathrm{~d}, J=16 \mathrm{~Hz}, 1 \mathrm{H}) ;{ }^{13} \mathrm{C}-\mathrm{NMR}\left(\mathrm{CD}_{3} \mathrm{OD}\right): \delta(\mathrm{ppm}) 25.4\left(\mathrm{CH}_{2}\right), 27.3\left(\mathrm{CH}_{2}\right)$, $34.1\left(2 \times \mathrm{CH}_{2}\right), 39.3\left(\mathrm{CH}_{2}\right), 39.4\left(\mathrm{CH}_{2}\right), 40.2(\mathrm{CH}), 117.2(\mathrm{CH}), 118.1(\mathrm{CH}), 119.9(\mathrm{CH}), 121.7(\mathrm{C}), 130.7(\mathrm{C})$, $144.2(\mathrm{CH}), 147.7(\mathrm{C}), 147.8(\mathrm{C}), 168.2(\mathrm{C}), 174.8(\mathrm{C})$.

\subsection{Mushroom Tyrosinase Inhibition Assay}

One hundred microliters of a methanolic solution of LC were incubated in $2 \mathrm{~mL}(0.001-1 \mathrm{mM}$ final concentration) of $50 \mathrm{mM}$ phosphate buffer ( $\mathrm{pH} \mathrm{6.8)}$ ) at room temperature in the presence of mushroom tyrosinase $(20 \mathrm{U} / \mathrm{mL})$. After $10 \mathrm{~min} 20 \mu \mathrm{L}$ of a $100 \mathrm{mM}$ solution of L-DOPA or L-tyrosine in $0.6 \mathrm{M} \mathrm{HCl}$ ( $1 \mathrm{mM}$ final concentration) were added and the course of the reaction was followed spectrophotometrically measuring the absorbance at $475 \mathrm{~nm}$ for $10 \mathrm{~min}$ at $2 \mathrm{~min}$ intervals. In control experiments the reaction was run in the absence of LC. When required, the assay was performed as described but by adding L-DOPA to the reaction mixture soon after the addition of LC ( $3 \mu \mathrm{M})$.

In separate experiments, the assay was run as above with $\mathrm{LC}$ at $250 \mu \mathrm{M}$, in the presence or absence of L-DOPA, and after $10 \mathrm{~min}$ the mixture was analyzed by HPLC.

\subsection{Investigation of the Mechanism of Inhibition of Mushroom Tyrosinase Activity}

The assay was run as above, using different concentrations of L-DOPA $(0.125,0.25,0.5,1$, and $2 \mathrm{mM})$ and LC (0, 2, 3 and $5 \mu \mathrm{M})$. Data were elaborated to build the Lineweaver-Burk plot.

\subsection{Cell Viability Assay}

Cytotoxic effects on immortalized human keratinocytes $(\mathrm{HaCaT})$ were determined using the cell proliferation reagent MTT. Briefly, $5 \times 10^{3}$ cells were seeded into a 96-well plate and were incubated overnight at $37^{\circ} \mathrm{C}$ with $5 \% \mathrm{CO}_{2}$. Medium was then replaced with $100 \mu \mathrm{L}$ of fresh media containing $\mathrm{LC}$ at $0-30 \mu \mathrm{M}$ and cells were incubated at $37{ }^{\circ} \mathrm{C}$ with $5 \% \mathrm{CO}_{2}$. After 24,48 , or $72 \mathrm{~h}$ the LC-containing medium was removed, and $100 \mu \mathrm{L}$ of fresh medium without red phenol, containing 10\% MTT reagent, were added to each well and cells were incubated for $4 \mathrm{~h}$ at $37^{\circ} \mathrm{C}$ in the dark. Subsequently, the absorbance at $570 \mathrm{~nm}$ was measured in a microtiter plate reader (SINERGY H4, BioTek, AHSI S.P.A., Milan, Italy) and cell viability was expressed as the mean \pm standard deviation (SD) percentage compared to control. 


\section{Results and Discussion}

\subsection{Preparation of 2-S-Lipoylcaffeic Acid}

The synthesis of LC was carried out by adapting a procedure previously reported for the preparation of the conjugation product of hydroxytyrosol with DHLA [30]. This involved the generation of the $o$-quinone of caffeic acid by the regioselective hydroxylation of $p$-coumaric acid with 2-iodoxybenzoic acid (IBX) [42], followed by addition of DHLA. The product was obtained in pure form in ca. $20 \%$ yield by a sequential extraction with solvents of increasing polarity, without the need for any chromatographic purification step. NMR, MS, and UV-Vis analysis confirmed the identity of the compound as the conjugation product of DHLA with caffeic acid quinone via the C-2 of the aromatic ring $[43,44]$.

\subsection{Inhibition of the Catecholase Activity of Mushroom Tyrosinase by 2-S-Lipoylcaffeic Acid}

The enzyme inhibition properties of LC were investigated using mushroom tyrosinase, which is routinely used for preliminary assessment of the activity of potential tyrosinase inhibitors [45-47]. For the assay of catecholase activity, L-DOPA was used as the substrate. The assay is based on the spectrophotometric monitoring of dopachrome formation (wavelength of maximum absorbance $\left(\lambda_{\max }\right)$ $475 \mathrm{~nm}$ ), following oxidative cyclization of dopaquinone produced by tyrosinase-induced oxidation of the substrate, in the presence and in the absence of the inhibitor [48] (Scheme 1).

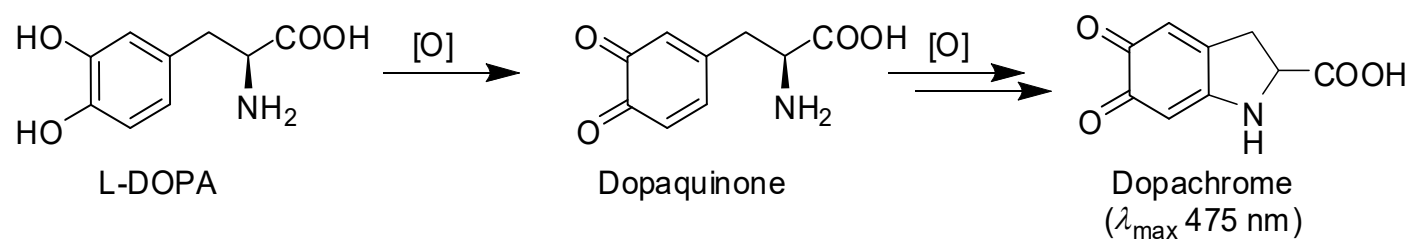

Scheme 1. Dopachrome formation by tyrosinase-catalyzed oxidation of 3,4-dihydroxy-L-phenylalanine (L-DOPA). $\lambda_{\max }$ : Wavelength of maximum absorbance.

LC was incubated in $50 \mathrm{mM}$ phosphate buffer $(\mathrm{pH}$ 6.8) in the presence of mushroom tyrosinase $(20 \mathrm{U} / \mathrm{mL})$ at room temperature. After $10 \mathrm{~min}$ L-DOPA ( $1 \mathrm{mM}$ final concentration) was added and the absorbance at $475 \mathrm{~nm}$ was measured at different times (Figure 2).

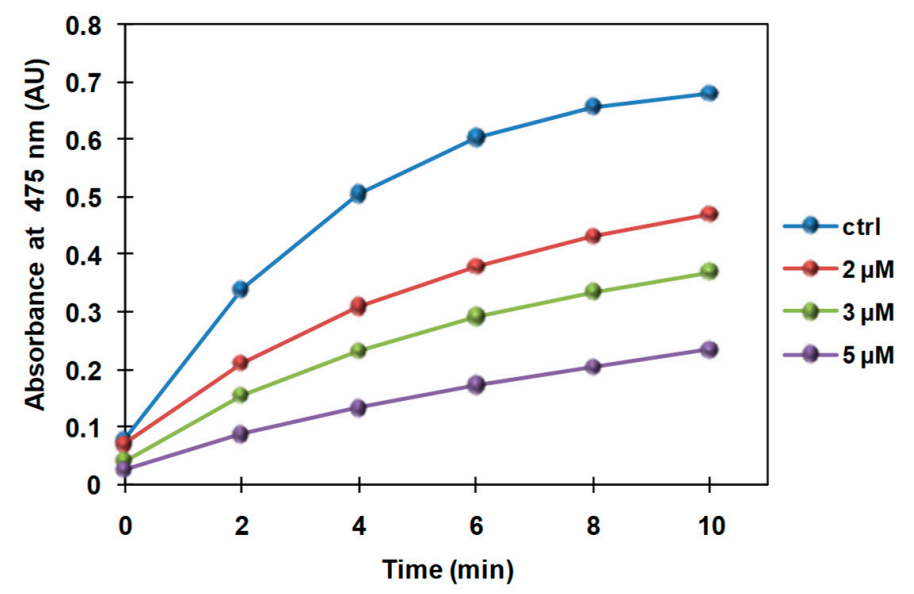

Figure 2. Time course of the absorbance change at $475 \mathrm{~nm}$ in the oxidation mixture of L-DOPA $(1 \mathrm{mM})$ with mushroom tyrosinase in the absence (control (ctrl)) or presence of different concentrations of LC. Reported are the mean values of at least three experiments (standard deviation (SD) $<5 \%$ ). AU: Arbitrary units. 
The percentage of inhibition was calculated using the following Equation:

$$
\% \text { inhibition }=\left(1-\frac{\Delta \mathrm{A}_{475 / \min } \text { in the presence of the inhibitor }}{\Delta \mathrm{A}_{475 / \min } \text { in the absence of the inhibitor }}\right) \times 100
$$

As reported in Figure 3, a maximum 80\% inhibition was observed with $5 \mu \mathrm{M} \mathrm{LC}$. A half maximum inhibitory concentration $\left(\mathrm{IC}_{50}\right)$ value of $3.22 \pm 0.02 \mu \mathrm{M}$ was determined.

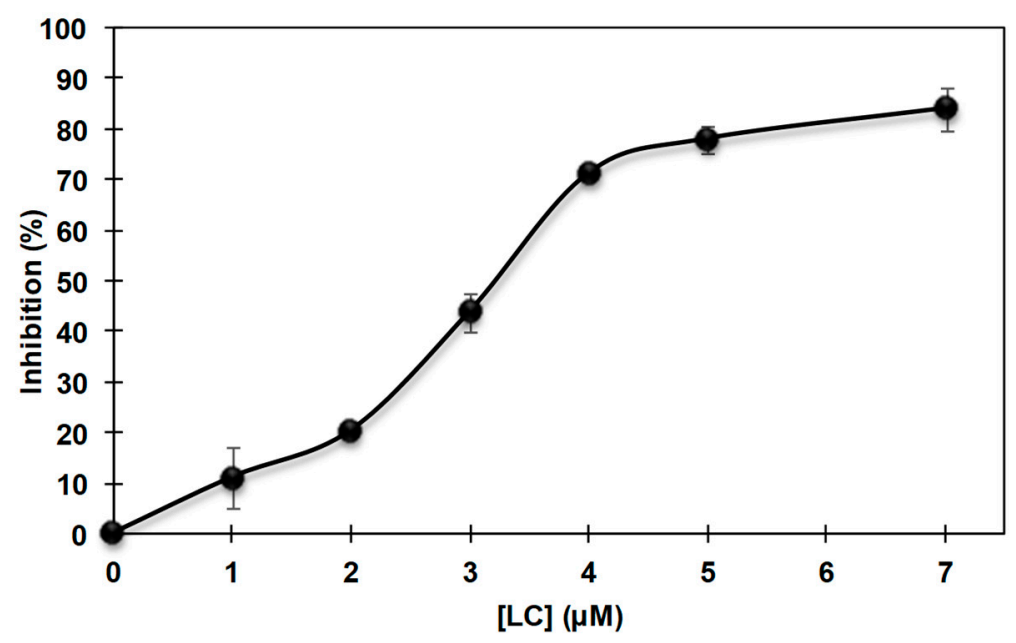

Figure 3. Percent of inhibition of mushroom tyrosinase activity vs. LC concentration using L-DOPA $(1 \mathrm{mM})$ as substrate. Reported are the mean \pm SD values of at least three experiments.

Figure 4 shows the inhibition effect of $10 \mu \mathrm{M}$ LC on the formation of dopachrome when L-DOPA is incubated with mushroom tyrosinase under the conditions previously described. Notably, at the same concentration, caffeic acid and the well-established tyrosinase inhibitor kojic acid $[49,50]$ did not induce any inhibition.

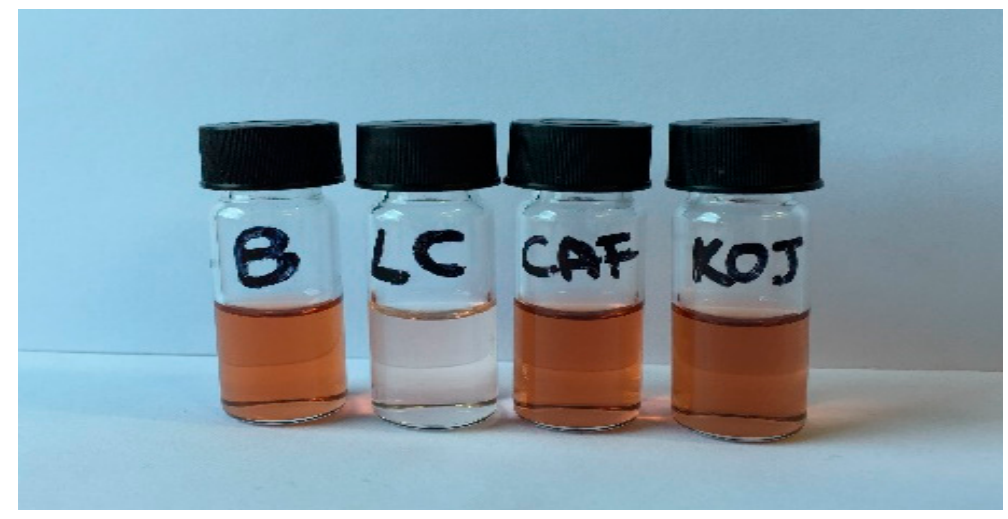

Figure 4. Tyrosinase-catalyzed oxidation mixtures of L-DOPA $(1 \mathrm{mM})$ in the absence (B) or in the presence of $10 \mu \mathrm{M}$ inhibitor (LC: 2-S-lipoylcaffeic acid; CAF: Caffeic acid; KOJ: Kojic acid).

These results not only show the superior inhibition properties of LC, but also underline the importance of the functionalization with DHLA in imparting tyrosinase inhibition properties to the parent catechol caffeic acid. It is well known that insertion of a chalcogen can affect the properties of catechol systems by lowering the $\mathrm{O}-\mathrm{H}$ bond dissociation enthalpy $[29,51,52]$. However, the possibility that the higher inhibitory activity observed following conjugation with DHLA is not due to the presence of the sulfur substituent, per se, but rather to the hydrophobicity acquired by the compound 
cannot be excluded. Actually, the tyrosinase inhibition properties of caffeoyl-amino acidyl-hydroxamic acid derivatives have been ascribed in part to their hydrophobicity, making them suitable for binding to the active site of tyrosinase [26-28].

On the other hand, the primary sulfhydryl group of DHLA has been reported to react with dopaquinone produced by the tyrosinase-catalyzed oxidation of L-DOPA, leading to the formation of covalent lipoyl adducts and inhibiting dopachrome formation [38,39]. Given the presence of a free, although secondary, SH group, in separate experiments the possibility that LC could react with dopaquinone in the same way was investigated: the assay was run under the usual conditions and after 10 min the mixture was analyzed by HPLC which, however, did not reveal any consumption of the inhibitor nor formation of new products, ruling out a possible reaction of LC with the oxidation products of L-DOPA.

These results also suggested that LC is not an alternative substrate of the enzyme, since no consumption was observed even in the absence of L-DOPA. This is an issue of considerable importance, since the toxicity of some depigmenting agents has been mostly attributed to their acting as substrates of tyrosinase and, as such, being oxidized by the enzyme, leading to the formation of highly reactive, cytotoxic o-quinones $[47,53,54]$.

Finally, the effect of pre-incubation on the inhibitory activity was investigated, by performing the spectrophotometric assay as above but with the addition of L-DOPA to the reaction mixture immediately after addition of LC. The time course of the absorbance change at $475 \mathrm{~nm}$ was comparable to that observed when LC was preincubated with the enzyme for 10 min before addition of L-DOPA, ruling out any role of pre-incubation in the inhibition effects exerted by LC.

\subsection{Inhibition of the Cresolase Activity of Mushroom Tyrosinase by 2-S-Lipoylcaffeic Acid}

The ability of LC to inhibit the monophenolasic activity of mushroom tyrosinase was investigated as described above using L-tyrosine instead of L-DOPA as substrate (Figure 5). An $\mathrm{IC}_{50}$ value of $2.0 \pm 0.1 \mu \mathrm{M}$ was determined.

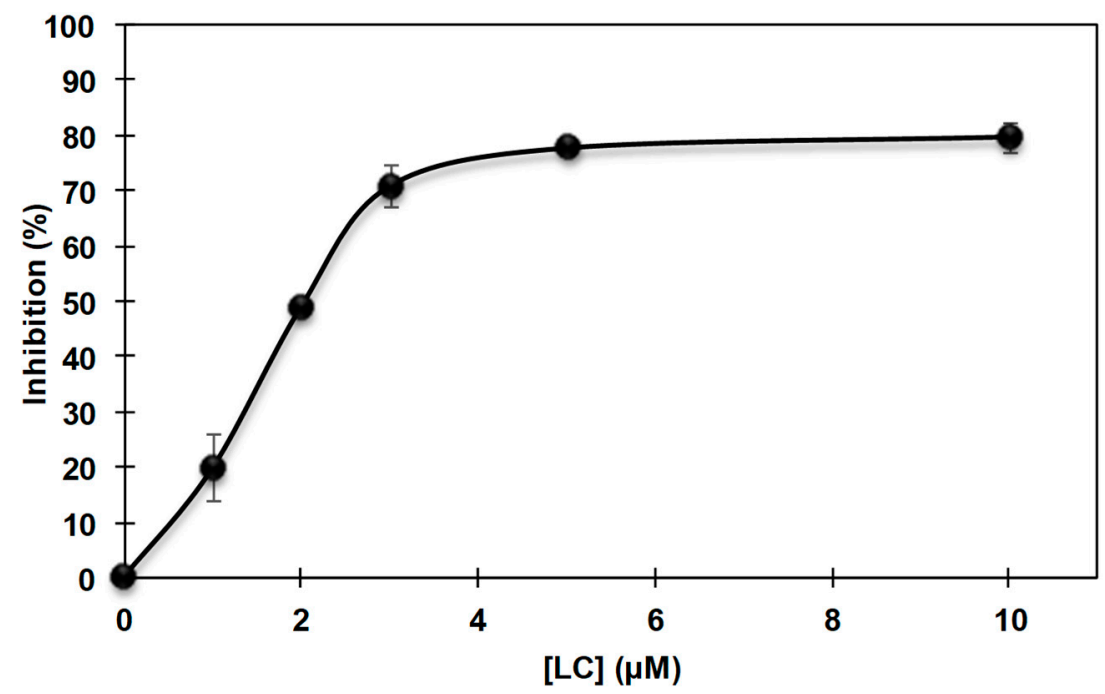

Figure 5. Percent of inhibition of mushroom tyrosinase activity vs. LC concentration using L-tyrosine $(1 \mathrm{mM})$ as the substrate. Reported are the mean \pm SD values of at least three experiments.

\subsection{Investigation of the Mechanism of Inhibition of Mushroom Tyrosinase Activity by 2-S-Lipoylcaffeic Acid}

Lineweaver-Burk plot analysis was used to determine the mode of tyrosinase inhibition by LC. In Figure 6 the double-reciprocal plots of tyrosinase inhibition using L-DOPA as substrate is reported for different concentrations $(0,3$, and $5 \mu \mathrm{M})$ of LC. 


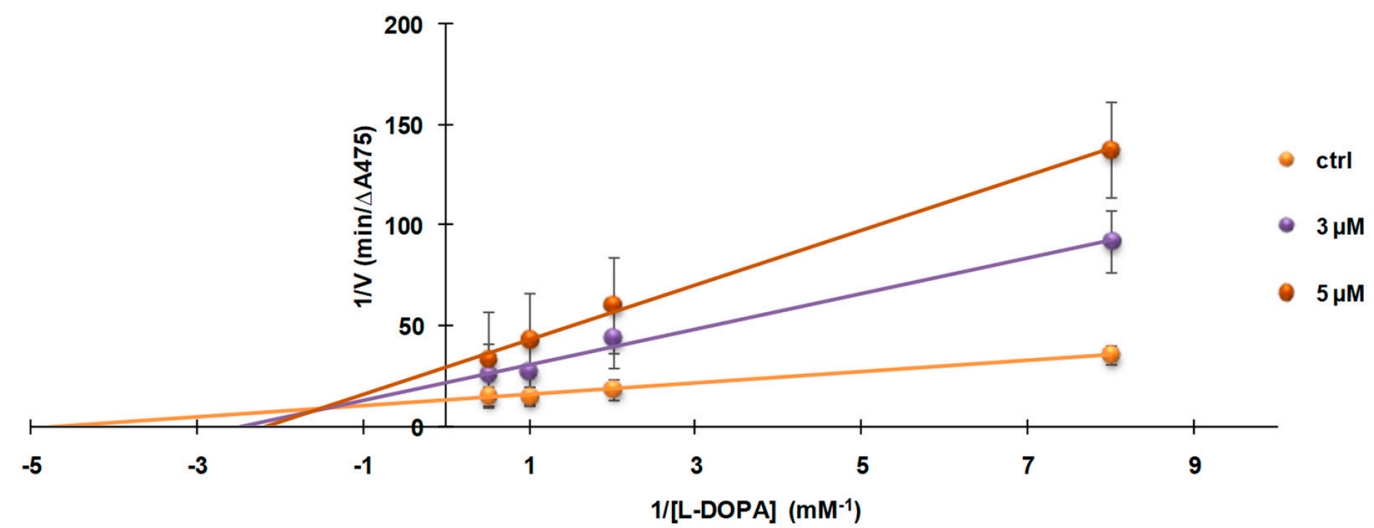

Figure 6. Lineweaver-Burk plot for the inhibition of mushroom tyrosinase-catalyzed L-DOPA oxidation by LC at 0 (control (ctrl)), 3 or $5 \mu \mathrm{M}$. Data were obtained as mean \pm SD values of $1 / \mathrm{V}$, inverse of the increase of absorbance at $475 \mathrm{~nm}$ per $\min \left(\Delta \mathrm{A}_{475} / \mathrm{min}\right)$, of three independent experiments with different concentrations of L-DOPA.

The results were a family of straight lines with different slopes and different $x$ - and $y$-intercepts, suggestive of a mixed inhibitor, lowering the maximum rate $\left(V_{\max }\right)$ and increasing the Michaelis constant $K_{m}$ in a dose dependent-manner (Figure 7).

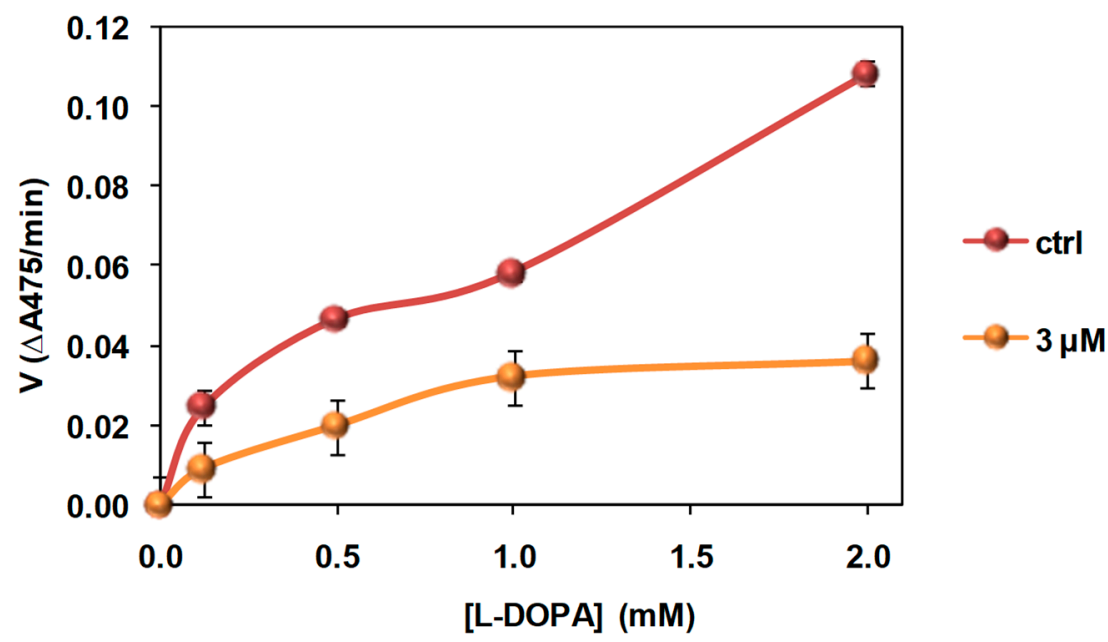

Figure 7. The effect of LC on the enzymatic kinetics for the mushroom tyrosinase-induced oxidation of L-DOPA. Data were obtained as mean $\pm \mathrm{SD}$ values of the increase of absorbance at $475 \mathrm{~nm}$ per min $\left(\Delta \mathrm{A}_{475} / \mathrm{min}\right)(\mathrm{V})$ of three independent experiments with different concentrations of L-DOPA.

Several mixed-type inhibitors of mushroom tyrosinase have been described in the literature and, in most cases, complex kinetics are involved and the phenomena have been left unexplained. Recently, non-specific binding sites have been invoked to explain the mixed-type inhibition in mushroom tyrosinase activities [55]. However, in our case, available data do not allow discussion in more detail of how the ternary complex of substrate-enzyme-inhibitor is formed, to assess whether the free thiol group participates in the inhibition mechanism and by what mechanism, and what the role of the hydrophobic aliphatic chain of the DHLA residue is.

\subsection{Cytotoxicity Evaluation}

With the aim of evaluating the possible use of LC as a tyrosinase inhibitor in vivo, its cytotoxicity was preliminarily evaluated on human keratinocyte cells $(\mathrm{HaCaT})$ by performing the MTT assay $[52,56]$. 
As shown in Figure 8, HaCat cells did not exhibit any significant reduction in proliferation rate when incubated with increasing amounts of LC over $72 \mathrm{~h}$.

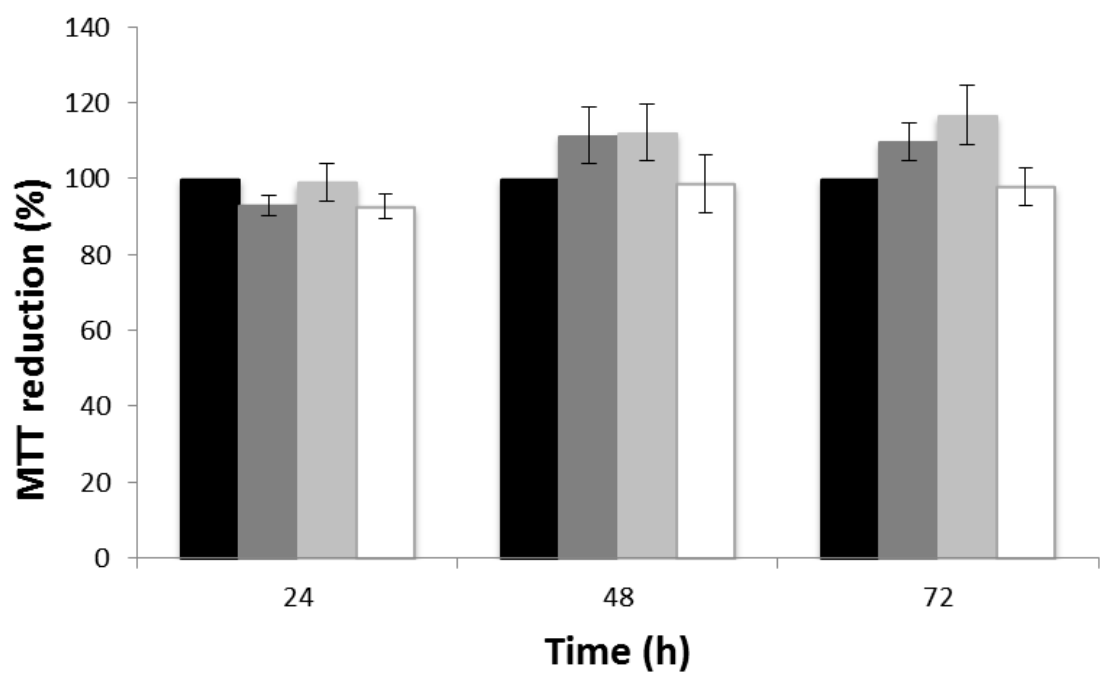

Figure 8. Effect of LC on HaCaT cell viability determined by 3-(4,5-dimethyl-2-thiazolyl)-2,5diphenyl-2H-tetrazolium bromide (MTT) assay. Cells were cultured in normal growth medium and then subjected to treatment with LC (black: Control; dark grey: $0.3 \mu \mathrm{M}$; grey: $3 \mu \mathrm{M}$; white: $30 \mu \mathrm{M}$ ) for 24,48 , and $72 \mathrm{~h}$. Cell viability was evaluated by measuring the $\mathrm{A}_{570 \mathrm{~nm}}$. Results are expressed as the percentage (means \pm SD from at least three experiments) compared to the control.

\section{Conclusions}

The use of natural catechols and derivatives as tyrosinase inhibitors for the treatment of pigmentary disorders associated with the overproduction or accumulation of melanin is well documented. We have reported herein that 2-S-lipoylcaffeic acid (LC), the S-conjugation product of caffeic acid and dihydrolipoic acid, is a promising lead structure for the development of catechol-based natural product-like tyrosinase inhibitors. LC was found to be able to inhibit both the catecholase and cresolase activity of mushroom tyrosinase with $\mathrm{IC}_{50}$ values as low as $3 \mu \mathrm{M}$, whereas under the same conditions caffeic acid did not show any effect, pointing to insertion of the dihydrolipoyl chain as an effective means of potentiating the inhibitory activity.

Whether this effect is due to the $S$-substituted catechol moiety alone or reflects the cooperative effect of the adjacent SH group cannot be assessed on the basis of the present data. It seems likely, however, that the potent inhibitory effects on tyrosinase reflect a synergic combination of caffeic acid as a substrate (L-DOPA)-like scaffold on which an efficient copper-binding arm (DHLA) is installed modulating catechol redox and chelating properties and conferring to the conjugate a higher degree of lipophilicity.

Although further experiments are needed to assess the actual potential of LC as a depigmenting agent in vivo, it is worth noting that the compound was non-toxic on immortalized human keratinocytes at concentrations up to $30 \mu \mathrm{M}$. Moreover, control experiments revealed that LC is not a substrate of tyrosinase, a critical issue for the toxicity of depigmenting agents in vivo. Although we are aware that additional, more cogent experiments are necessary to corroborate the lack of toxicity, the results of this paper can provide the necessary background for further studies on mammalian melanocyte cell lines, which will be directed to confirm activity on mammalian enzyme and pigment cells.

Overall, these results further expand the framework of the practical opportunities offered by the thiol-quinone coupling reactions, with particular reference to the dihydrolipoic/lipoic acid chemistry.

Author Contributions: L.P., A.N., and M.d.I. conceived and designed the experiments; R.M. and V.P. performed the experiments; E.P. and L.P. analyzed the data; and R.M., E.P., L.P., A.N., and M.d.I. wrote the paper. 
Conflicts of Interest: The authors declare no conflict of interest.

\section{References}

1. Slominski, A. Melanin pigmentation in mammalian skin and its hormonal regulation. Physiol. Rev. 2004, 84, 1155-1228. [CrossRef] [PubMed]

2. Yamaguchi, Y.; Hearing, V.J. Melanocytes and their diseases. Cold Spring Harb. Perspect. Med. 2014, 4. [CrossRef] [PubMed]

3. Cardinali, G.; Kovacs, D.; Picardo, M. Mechanisms underlying post-inflammatory hyperpigmentation: Lessons from solar lentigo. Ann. Dermatol. Venereol. 2012, 139 (Suppl. S4), S148-S152. [CrossRef]

4. Smit, N.; Vicanova, J.; Pavel, S. The hunt for natural skin whitening agents. Int. J. Mol. Sci. 2009, 10, 5326-5349. [CrossRef] [PubMed]

5. Picardo, M.; Carrera, M. New and experimental treatments of cloasma and other hypermelanoses. Dermatol. Clin. 2007, 25, 353-362. [CrossRef] [PubMed]

6. Gunia-Krzyżak, A.; Popiol, J.; Marona, H. Melanogenesis inhibitors: Strategies for searching for and evaluation of active compounds. Curr. Med. Chem. 2016, 23, 3548-3574. [CrossRef] [PubMed]

7. Ebanks, J.P.; Wickett, R.R.; Boissy, R.E. Mechanisms regulating skin pigmentation: The rise and fall of complexion coloration. Int. J. Mol. Sci. 2009, 10, 4066-4087. [CrossRef] [PubMed]

8. Slominski, A.; Zmijewski, M.A.; Pawelek, J. L-Tyrosine and L-dihydroxyphenylalanine as hormone-like regulators of melanocyte functions. Pigment Cell Melanoma Res. 2012, 25, 14-27. [CrossRef] [PubMed]

9. Pillaiyar, T.; Manickam, M.; Namasivayam, V. Skin whitening agents: Medicinal chemistry perspective of tyrosinase inhibitors. J. Enzym. Inhib. Med. Chem. 2017, 32, 403-425. [CrossRef] [PubMed]

10. Chang, T.S. An updated review of tyrosinase inhibitors. Int. J. Mol. Sci. 2009, 10, 2440-2475. [CrossRef] [PubMed]

11. Riley, P.A. Mechanistic aspects of the control of tyrosinase activity. Pigment Cell Res. 1993, 6, 182-185. [CrossRef] [PubMed]

12. Ito, S.; Wakamatsu, K. Chemistry of mixed melanogenesis-Pivotal roles of dopaquinone. Photochem. Photobiol. 2008, 84, 582-592. [CrossRef] [PubMed]

13. Lee, C.S.; Joo, Y.H.; Baek, H.S.; Park, M.; Kim, J.H.; Shin, H.J.; Park, N.H.; Lee, J.H.; Park, Y.H.; Shin, S.S.; et al. Different effects of five depigmentary compounds, rhododendrol, raspberry ketone, monobenzone, rucinol and AP736 on melanogenesis and viability of human epidermal melanocytes. Exp. Dermatol. 2016, 25, 44-49. [CrossRef] [PubMed]

14. Ito, S.; Hinoshita, M.; Suzuki, E.; Ojika, M.; Wakamatsu, K. Tyrosinase-catalyzed oxidation of the leukoderma-inducing agent raspberry ketone produces (E)-4-(3-oxo-1-butenyl)-1,2-benzoquinone: Implications for melanocyte toxicity. Chem. Res. Toxicol. 2017, 30, 859-868. [CrossRef] [PubMed]

15. Okura, M.; Yamashita, T.; Ishii-Osai, Y.; Yoshikawa, M.; Sumikawa, Y.; Wakamatsu, K.; Ito, S. Effects of rhododendrol and its metabolic products on melanocytic cell growth. J. Dermatol. Sci. 2015, 80, 142-149. [CrossRef] [PubMed]

16. Ito, S.; Ojika, M.; Yamashita, T.; Wakamatsu, K. Tyrosinase-catalyzed oxidation of rhododendrol produces 2-methylchromane-6,7-dione, the putative ultimate toxic metabolite: Implications for melanocyte toxicity. Pigment Cell Melanoma Res. 2014, 27, 744-753. [CrossRef] [PubMed]

17. Sasaki, M.; Kondo, M.; Sato, K.; Umeda, M.; Kawabata, K.; Takahashi, Y.; Suzuki, T.; Matsunaga, K.; Inoue, $\mathrm{S}$. Rhododendrol, a depigmentation-inducing phenolic compound, exerts melanocyte cytotoxicity via a tyrosinase-dependent mechanism. Pigment Cell Melanoma Res. 2014, 27, 754-763. [CrossRef] [PubMed]

18. Chen, C.Y.; Lin, L.C.; Yang, W.F.; Bordon, J.; Wang, H.M.D. An updated organic classification of tyrosinase inhibitors on melanin biosynthesis. Curr. Org. Chem. 2015, 19, 4-18. [CrossRef]

19. Pillaiyar, T.; Manickam, M.; Jung, S.H. Inhibitors of melanogenesis: A patent review (2009-2014). Expert Opin. Ther. Pat. 2015, 25, 775-788. [CrossRef] [PubMed]

20. Munoz-Munoz, J.L.; Berna, J.; Garcia-Molina, F.; Garcia-Ruiz, P.A.; Tudela, J.; Rodriguez-Lopez, J.N.; Garcia-Canovas, F. Unravelling the suicide inactivation of tyrosinase: A discrimination between mechanisms. J. Mol. Catal. B Enzym. 2012, 75, 11-19. [CrossRef] 
21. Xue, Y.L.; Miyakawa, T.; Hayashi, Y.; Okamoto, K.; Hu, F.; Mitani, N.; Furihata, K.; Sawano, Y.; Tanokura, M. Isolation and tyrosinase inhibitory effects of polyphenols from the leaves of persimmon, Diospyros kaki. J. Agric. Food Chem. 2011, 59, 6011-6017. [CrossRef] [PubMed]

22. Silva, T.; Oliveira, C.; Borges, F. Caffeic acid derivatives, analogs and applications: A patent review (2009-2013). Expert Opin. Ther. Pat. 2014, 24, 1257-1270. [CrossRef] [PubMed]

23. Magnani, C.; Isaac, V.L.B.; Correa, M.A.; Salgado, H.R.N. Caffeic acid: A review of its potential use in medications and cosmetics. Anal. Methods 2014, 6, 3203-3210. [CrossRef]

24. Touaibia, M.; Jean-Francois, J.; Doiron, J. Caffeic acid, a versatile pharmacophore: An overview. Mini Rev. Med. Chem. 2011, 11, 695-713. [CrossRef] [PubMed]

25. Kuo, Y.H.; Chen, C.C.; Lin, P.; You, Y.J.; Chiang, H.M. N-(4-Bromophenethyl) caffeamide inhibits melanogenesis by regulating AKT/glycogen synthase kinase $3 \beta /$ microphthalmia-associated transcription factor and tyrosinase-related protein 1/tyrosinase. Curr. Pharm. Biotechnol. 2015, 16, 1111-1119. [CrossRef] [PubMed]

26. Kwak, S.Y.; Yang, J.K.; Choi, H.R.; Park, K.C.; Kim, Y.B.; Lee, Y.S. Synthesis and dual biological effects of hydroxycinnamoyl phenylalanyl/prolyl hydroxamic acid derivatives as tyrosinase inhibitor and antioxidant. Bioorg. Med. Chem. Lett. 2013, 23, 1136-1142. [CrossRef] [PubMed]

27. Kwak, S.Y.; Lee, S.; Choi, H.R.; Park, K.C.; Lee, Y.S. Dual effects of caffeoyl-amino acidyl-hydroxamic acid as an antioxidant and depigmenting agent. Bioorg. Med. Chem. Lett. 2011, 21, 5155-5158. [CrossRef] [PubMed]

28. Tada, T.; Ohnishi, K.; Komiya, T.; Imai, K. Synthetic search for cosmetic ingredients: Preparations, tyrosinase inhibitory and antioxidant activities of caffeic amides. J. Oleo Sci. 2002, 51, 19-27. [CrossRef]

29. Amorati, R.; Valgimigli, L.; Panzella, L.; Napolitano, A.; d'Ischia, M. 5-S-Lipoylhydroxytyrosol, a multidefense antioxidant featuring a solvent-tunable peroxyl radical-scavenging 3-thio-1,2-dihydroxybenzene motif. J. Org. Chem. 2013, 78, 9857-9864. [CrossRef] [PubMed]

30. Panzella, L.; Verotta, L.; Goya, L.; Ramos, S.; Martin, M.A.; Bravo, L.; Napolitano, A.; d'Ischia, M. Synthesis and bioactivity profile of 5-S-lipoylhydroxytyrosol-based multidefense antioxidants with a sizeable (poly)sulfide chain. J. Agric. Food Chem. 2013, 61, 1710-1717. [CrossRef] [PubMed]

31. Greco, G.; Panzella, L.; Pezzella, A.; Napolitano, A.; d'Ischia, M. Reaction of dihydrolipoic acid with juglone and related naphthoquinones: Unmasking of a spirocyclic 1,3-dithiane intermediate en route to naphtho[1,4]dithiepines. Tetrahedron 2010, 66, 3912-3916. [CrossRef]

32. De Lucia, M.; Panzella, L.; Pezzella, A.; Napolitano, A.; d'Ischia, M. Plant catechols and their S-glutathionyl conjugates as antinitrosating agents: Expedient synthesis and remarkable potency of 5-S-glutathionylpiceatannol. Chem. Res. Toxicol. 2008, 21, 2407-2413. [CrossRef] [PubMed]

33. Panzella, L.; De Lucia, M.; Napolitano, A.; d'Ischia, M. The first expedient entry to the human melanogen 2-S-cysteinyldopa exploiting the anomalous regioselectivity of 3,4-dihydroxycinnamic acid-thiol conjugation. Tetrahedron Lett. 2007, 48, 7650-7652. [CrossRef]

34. Panzella, L.; Napolitano, A.; d'Ischia, M. Oxidative conjugation of chlorogenic acid with glutathione. Structural characterization of addition products and a new nitrite-promoted pathway. Bioorg. Med. Chem. 2003, 11, 4797-4805. [CrossRef]

35. Panzella, L.; Napolitano, A.; d'Ischia, M. Nitrite-mediated decarboxylative conjugation of caffeic acid with glutathione under mildly acidic conditions. Bioorg. Med. Chem. Lett. 2002, 12, 3547-3550. [CrossRef]

36. Packer, L.; Witt, E.H.; Tritschler, H.J. $\alpha$-Lipoic acid as a biological antioxidant. Free Radic. Biol. Med. 1995, 19, 227-235. [CrossRef]

37. Rochette, L.; Ghibu, S.; Richard, C.; Zeller, M.; Cottin, Y.; Vergely, C. Direct and indirect antioxidant properties of $\alpha$-lipoic acid and therapeutic potential. Mol. Nutr. Food Res. 2013, 57, 114-122. [CrossRef] [PubMed]

38. Tsuji-Naito, K.; Hatani, T.; Okada, T.; Tehara, T. Evidence for covalent lipoyl adduction with DOPAquinone following tyrosinase-catalyzed oxidation. Biochem. Biophys. Res. Commun. 2006, 343, 15-20. [CrossRef] [PubMed]

39. Tsuji-Naito, K.; Hatani, T.; Okada, T.; Tehara, T. Modulating effects of a novel skin-lightening agent, $\alpha$-lipoic acid derivative, on melanin production by the formation of DOPA conjugate products. Bioorg. Med. Chem. 2007, 15, 1967-1975. [CrossRef] [PubMed]

40. Frigerio, M.; Santagostino, M.; Sputore, S. A user-friendly entry to 2-iodoxybenzoic acid (IBX). J. Org. Chem. 1999, 64, 4537-4538. [CrossRef] 
41. Gunsalus, I.C.; Barton, L.S.; Gruber, W. Biosynthesis and structure of lipoic acid derivatives. J. Am. Chem. Soc. 1956, 78, 1763-1766. [CrossRef]

42. Bernini, R.; Fabrizi, G.; Pouysegu, L.; Deffieux, D.; Quideau, S. Synthesis of biologically active catecholic compounds via ortho-selective oxygenation of phenolic compounds using hypervalent iodine $(\mathrm{V})$ reagents. Curr. Org. Synth. 2012, 9, 650-669. [CrossRef]

43. Guerriero, E.; Sorice, A.; Capone, F.; Costantini, S.; Palladino, P.; d'Ischia, M.; Castello, G. Effects of lipoic acid, caffeic acid and a synthesized lipoyl-caffeic conjugate on human hepatoma cell lines. Molecules 2011, 16, 6365-6377. [CrossRef] [PubMed]

44. Ferreira-Lima, N.; Vallverdu-Queralt, A.; Meudec, E.; Mazauric, J.-P.; Sommerer, N.; Bordignon-Luiz, M.T.; Cheynier, V.; Le Guerneve, C. Synthesis, identification, and structure elucidation of adducts formed by reactions of hydroxycinnamic acids with glutathione or cysteinylglycine. J. Nat. Prod. 2016, 79, 2211-2222. [CrossRef] [PubMed]

45. Solano, F.; Briganti, S.; Picardo, M.; Ghanem, G. Hypopigmenting agents: An updated review on biological, chemical and clinical aspects. Pigment Cell Res. 2006, 19, 550-571. [CrossRef] [PubMed]

46. Jones, K.; Hughes, J.; Hong, M.; Jia, Q.; Orndorff, S. Modulation of melanogenesis by aloesin: A competitive inhibitor of tyrosinase. Pigment Cell Res. 2002, 15, 335-340. [CrossRef] [PubMed]

47. Ito, S.; Wakamatsu, K. A convenient screening method to differentiate phenolic skin whitening tyrosinase inhibitors from leukoderma-inducing phenols. J. Dermatol. Sci. 2015, 80, 18-24. [CrossRef] [PubMed]

48. Mason, H.S. The chemistry of melanin: III. Mechanism of the oxidation of dihydroxyphenylalanine by tyrosinase. J. Biol. Chem. 1948, 172, 83-99. [PubMed]

49. Battaini, G.; Monzani, E.; Casella, L.; Santagostini, L.; Pagliarin, R. Inhibition of the catecholase activity of biomimetic dinuclear copper complexes by kojic acid. J. Biol. Inorg. Chem. 2000, 5, 262-268. [CrossRef] [PubMed]

50. Kahn, V. Effect of kojic acid on the oxidation of DL-DOPA, norepinephrine, and dopamine by mushroom tyrosinase. Pigment Cell Res. 1995, 8, 234-240. [CrossRef] [PubMed]

51. Amorati, R.; Fumo, M.G.; Menichetti, S.; Mugnaini, V.; Pedulli, G.F. Electronic and hydrogen bonding effects on the chain-breaking activity of sulfur-containing phenolic antioxidants. J. Org. Chem. 2006, 71, 6325-6332. [CrossRef] [PubMed]

52. Tanini, D.; Panzella, L.; Amorati, R.; Capperucci, A.; Pizzo, E.; Napolitano, A.; Menichetti, S.; d'Ischia, M. Resveratrol-based benzoselenophenes with an enhanced antioxidant and chain breaking capacity. Org. Biomol. Chem. 2015, 13, 5757-5764. [CrossRef] [PubMed]

53. Riley, P.A.; Cooksey, C.J.; Johnson, C.I.; Land, E.J.; Latter, A.M.; Ramsden, C.A. Melanogenesis-targeted anti-melanoma pro-drug development: Effect of side-chain variations on the cytotoxicity of tyrosinase-generated ortho-quinones in a model screening system. Eur. J. Cancer 1997, 33, 135-143. [CrossRef]

54. Cooksey, C.J.; Land, E.J.; Ramsden, C.A.; Riley, P.A. Tyrosinase-mediated cytotoxicity of 4-substituted phenols: Quantitative structure-thiol-reactivity relationships of the derived o-quinones. Anticancer Drug Des. 1995, 10, 119-122. [CrossRef] [PubMed]

55. Hassani, S.; Haghbeen, K.; Fazli, M. Non-specific binding sites help to explain mixed inhibition in mushroom tyrosinase activities. Eur. J. Med. Chem. 2016, 122, 138-148. [CrossRef] [PubMed]

56. Mosmann, T. Rapid colorimetric assay for cellular growth and survival: Application to proliferation and cytotoxicity assays. J. Immunol. Methods 1983, 65, 55-63. [CrossRef]

(C) 2017 by the authors. Licensee MDPI, Basel, Switzerland. This article is an open access article distributed under the terms and conditions of the Creative Commons Attribution (CC BY) license (http://creativecommons.org/licenses/by/4.0/). 